\title{
Variation in the position of resin canals in the needles of Abies species and provenances
}

\author{
KP Panetsos \\ University of Thessaloniki, Laboratory of Forest Genetics and Plant Breeding, \\ 54006 Thessaloniki, Greece
}

(Received 14 December 1991; accepted 11 February 1992)

\begin{abstract}
Summary - The position of resin canals in the needles of Abies species, hybrids and provenances were studied by sampling 21 -year-old plants in a species and provenance field experiment. It was found that at an early age all species and provenances develop needles with marginal resin canals. However, in the hybrids and also in some species and provenances, 2 types of adult tree were distinguished: a) trees with marginal resin canals throughout the crown; and b), trees with marginal resin canals in the lower part of the crown followed by a transitional zone where all stages are manifested; finally the position becomes median in the needles in the rest of their crown. The frequency of the 2 types of tree varies between species and hybrids and also among provenances within species. The position of the resin canals and the variation detected is discussed with regard to its origin and its significance to the taxonomy and evolution of the genus Abies.
\end{abstract}

\section{Abies spp = fir $/$ resin canal position / variation / evolution}

Résumé - Variation de la position des canaux résinifères des aiguilles des espèces et provenances de sapin abies. La position des canaux résinifères au sein des aiguilles des espèces, provenances et hybrides de sapin abies a été étudiée en échantillonnant des individus âgés de 21 ans dans un dispositif expérimental de comparaison d'espèces et de provenances.

On a observé que les canaux résinifères étaient marginaux dans toutes les espèces et provenances au cours des premiers stades de leur développement.

Toutefois, chez les hybrides ainsi que chez certaines espèces et provenances, 2 types d'arbres âgés peuvent être distingués : (a) arbres avec canaux résinifères marginaux tout le long de la cime, (b) arbres avec canaux résinifères marginaux à la partie inférieure de leur cime et suivie par une zone de transition où tous les stades peuvent se manifester, et enfin la position devient "médiane" au sein de l'aiguille dans le reste de leur cime. La fréquence des 2 genres d'arbres varie entre les espèces et les hybrides ainsi que parmi les provenances de la même espèce.

Cette variation observée dans la position des canaux résinifères a été discutée en tenant compte de son origine et de son importance pour la taxonomie et l'étude de l'évolution du genre Abies.

Abies spp = espèces de sapin / position des canaux résinifères / variation / évolution 


\section{INTRODUCTION}

The position of the resin canals in the needles of fir species and occasionally their number, are considered as essential characters in the taxonomy of the genus Abies, although in certain species these may be changed, in relation to sterile and cone bearing branchlets (Liu, 1971). In the past this particular character was even used to separate the genus into 2: Marginal and Central sections (Patschke, 1913; Ferré, 1941).

The number of the resin canals in most of the fir species is 2, but in some cases it can be more than 2. A firma often has 4 resin canals and $A$ hicheli 8 to 12 in each needle.

The 2 resin canals, which are circular in shape, are located in the spongy tissue of the needle and may occupy different positions in relation to both the hypodermis and epidermis. After a review of the terminology used to describe the position of the resin canals in the Abietineae, Ferré (1941) proposed the distinction of 6 types according to their exact location in respect to epidermis, hypodermis and endodermis. Liu (1971) in his monograph on the genus Abies, distinguishes 2 types of resin canal; marginal when they touch the cells of the hypodermis or even those of the needle epidermis, and median when they are located in the mesophyll, ie, they are in a position between the endodermis and the outer angles of the needle, no matter whether nearer to the endodermis or not. The same terminology was used by a number of other investigators of the genus Abies to describe the position of the resin canals (Bassiotis, 1956; Klaehn and Winieski, 1962; Roller, 1966; Panetsos, 1975; Kormutäk, 1985; Moulalis, 1986).

Liu (1971) mentioned that there is a tendency of the resin canals to often move from the margin towards the mesophyll in leaves of fertile branchlets. In A firma, for example, the normal position in adult trees is median, whereas in young trees up to certain stage, the canals are marginal. In $A$ pinsapo (Liu, 1971; Catalan and Pardos, 1983) the resin canals are median, while in Morocco varieties (var morocana; var tazoana) they are maginal. It appears that the character varies within the same species.

According to Bassiotis (1956) in the Greek fir (Abies cephalonica) the 2 resin canals of the shaded needles of the lower branches of the trees are marginal, whereas in branches exposed to sunlight they are median. For the same species (Liu, 1971) distinguishes 2 varieties, A cephaIonica var cephalonica with 2 marginal resin canals and also A cephalonica var greaca (Fraas) Liu comb nov, growing on Mount Parnassos with marginal resin canals in the leaves of sterile branchlets, and median in the leaves of cone-bearing branchlets. In this variety, the abovementioned author also includes the species $A$ equitrojani (which occurs in Asia Minor) because it seems to be botanically identical to Mount Parnassos fir. As pointed out by Bassiotis (1956), Panetsos (1975), Mitsopoulos and Panetsos (1987), it is not possible to distinguish varieties within the species $A$ cephalonica and furthermore, there is no relation botanical or biochemical among the populations growing on Mount Parnassos and $A$ equi trojani.

Roller (1966) referring to A cephalonica stated "It will be desirable to examine species of Abies with median resin canals as A cephalonica Loudon, in order to determine whether or not the needles of the seedlings have peripheral resin canals". Kormutäk (1985) using 2-4-year-old seedlings in a comparative study of needle anatomy involving artificially produced hybrids and the corresponding parental species ( $A$ alba, A nordmaniana, A cephaloni- 
Table I. Identification of provenances or species. Frequencies of trees with marginal resin canals.

\begin{tabular}{|c|c|c|c|c|c|}
\hline $\mathrm{Cd}$ No & $\begin{array}{l}\text { Provenances * } \\
\text { or species }\end{array}$ & $\begin{array}{l}\text { Frequency of trees } \\
\text { with marginal } \\
\text { resin canals } \\
X \quad S D\end{array}$ & Latitude & Longitude & Altitude \\
\hline 1 & Taygetos & $0.88 \pm 0.06499$ & $37^{\circ} 00^{\prime}$ & $22^{\circ} 18^{\prime}$ & $1200-1400$ \\
\hline 2 & Parnonas & $0.83 \pm 0.07512$ & $37^{\circ} 07^{\prime}$ & $22^{\circ} 45^{\prime}$ & $1000-1400$ \\
\hline 3 & Vytina & $0.93 \pm 0.05102$ & $37^{\circ} 35^{\prime}$ & $22^{\circ} 15^{\prime}$ & $1200-1400$ \\
\hline 4 & Parnetha & $0.60 \pm 0.09797$ & $38^{\circ} 10^{\prime}$ & $23^{\circ} 41^{\prime}$ & $1100-1300$ \\
\hline 5 & Caphallonia & $0.65 \pm 0.09539$ & $387^{\circ} 14^{\prime}$ & $20^{\circ} 32^{\prime}$ & $1300-1500$ \\
\hline 6 & Euboea & $0.29 \pm 0.09075$ & $38^{\circ} 40^{\prime}$ & $23^{\circ} 30^{\prime}$ & $1200-1400$ \\
\hline 7 & Elikonas & $0.87 \pm 0.06726$ & $38^{\circ} 17^{\prime}$ & $22^{\circ} 15^{\prime}$ & $1400-1600$ \\
\hline 8 & Parnassos & $0.41 \pm 0.09836$ & $38^{\circ} 36^{\prime}$ & $22^{\circ} 30^{\prime}$ & $1400-1800$ \\
\hline 9 & Panaetolikon & $0.46 \pm 0.09967$ & $38^{\circ} 43^{\prime}$ & $21^{\circ} 36^{\prime}$ & $1400-1600$ \\
\hline 10 & Oete & $0.44 \pm 0.09927$ & $38^{\circ} 43^{\prime}$ & $22^{\circ} 10^{\prime}$ & $1000-1600$ \\
\hline 11 & Fourna & $0.24 \pm 0.08541$ & $39^{\circ} 03^{\prime}$ & $21^{\circ} 55^{\prime}$ & $1200-1400$ \\
\hline 12 & Aspropotamos & $0.26 \pm 0.08772$ & $39^{\circ} 38^{\prime}$ & $21^{\circ} 17^{\prime}$ & $1000-1400$ \\
\hline 13 & Agion oros & $0.44 \pm 0.09927$ & $40^{\circ} 11^{\prime}$ & $24^{\circ} 29^{\prime}$ & $900-1400$ \\
\hline 14 & Pieria & $0.25 \pm 0.08660$ & $40^{\circ} 21^{\prime}$ & $22^{\circ} 16^{\prime}$ & $1200-1400$ \\
\hline 15 & Konitsa & $0.44 \pm 0.09927$ & $40^{\circ} 06^{\prime}$ & $20^{\circ} 47^{\prime}$ & $1200-1400$ \\
\hline 16 & Aridea & $0.16 \pm 0.07332$ & $41^{\circ} 00^{\prime}$ & $21^{\circ} 50^{\prime}$ & $800-1200$ \\
\hline 17 & Abies equi trojani & $0.24 \pm 0.08541$ & \multirow{2}{*}{\multicolumn{3}{|c|}{$\begin{array}{l}\text { Ida mountain, Turkey } \\
\text { Turkey (unknown origin) }\end{array}$}} \\
\hline 18 & Abies bornmuelleriana & $0.41 \pm 0.09836$ & & & \\
\hline 19 & Abies alba (pr No 39) & $0.69 \pm 0.09249$ & $38^{\circ} 33^{i}$ & $16^{\circ} 20^{\prime}$ & $1100-1400$ \\
\hline 20 & Abies alba (pr No 12) & $0.55 \pm 0.09949$ & $41^{\circ} 53^{\prime}$ & $14^{\circ} 24^{\prime}$ & $850-1000$ \\
\hline 21 & Abies alba (pr No 65) & $0.18 \pm 0.07683$ & $43^{\circ} 48^{\prime}$ & $11^{\circ} 52^{\prime}$ & $1000-1200$ \\
\hline 22 & Abies alba (pr No 9) & $0.43 \pm 0.07683$ & $44^{\circ} 29^{\prime}$ & $7^{\circ} 53^{\prime}$ & $1100-1500$ \\
\hline 23 & Abies pinsapo & $0.00 \pm 0.00000$ & \multirow{2}{*}{\multicolumn{3}{|c|}{$\begin{array}{l}\text { Sierra de la Nieves, Spain } \\
\text { USA }\end{array}$}} \\
\hline 24 & Abies concolor & $1.00 \pm 0.00000$ & & & \\
\hline
\end{tabular}

*1-16 = Populations of Greek fir.

ca, A pinsapo, A numidica, A concolor, A cilicica, $A$ grandis, $A$ koreana), reports that the position of the resin canals was fixed marginally in all the parental species as well as in their artificial hybrids examined. Panetsos (1975), studying the position of resin canals in 5-year-old seedlings of a number of species, provenances and hybrids (see table I) found that it was rigidly fixed marginal in all 2-year-old needles examined. In a parallel study on needles sampled from mature trees in natural growing populations of Greek firs (A cephaloni- ca and hybrids) 2 kinds of tree were distinguished with respect the position of resin canals: a) trees with marginal resin canals throughout their crown; and b), trees with marginal resin canals in the lower part of their crown (1-2 $\mathrm{m}$ from the ground), following a transitional zone where all stages could be found and finally their position changed to median in the rest of the crown.

From the literature review it can be seen that the position of the resin canals in the needles of the genus Abies is highly vari- 
able, and uncertainty exists with respect to its variability pattern within and among species and even in the same tree.

The present study is a continuation of the work cited above (Panetsos, 1975) and has the following main objectives: a better understanding of the variability of this particular character, and its significance to taxonomy and evolution of the genus Abies.

\section{MATERIAL AND METHODS}

Needles samples were collected from trees growing at Merkada experimental plantation, which was established by 5-0 bare-rooted seedlings. The plantation is located in central Greece (lat $30^{\circ} 57^{\prime}$; long $21^{\circ} 56^{\prime}$; elev $950 \mathrm{~m}$ ) on Mount Tymphrestos. Seedlings were handplanted in a randomized incomplete block design, in 25-tree plots, at $3 \times 3 \mathrm{~m}$ intervals. The seedlings were raised from seeds collected by the Laboiatory of Forest Genetics and represent 16 populations scattered throughout the range of fir forests in Greece (table I). In addition, seeds of $A$ alba, $A$ equi trojani and $A$ bornmuelleriana were provided by Italian and Turkish collegues respectively. Seeds of $A$ concolor were obtained from the USA.

Sampling was carried out initially from 2 trees from each one of the 23 provenances and species in the plantation. Branchlets were collected from the lower middle and the whorl (previous year's growth) at the top of the tree, from 4 directions (east-west-north and south). Since no orientation-related difference was found in the position of the resin canals, sampling was restricted to one branchlet from the top whorl and one from the bottom on the south side of each tree.

In total, 25 trees from each provenance and species were sampled and 102 -year-old needles were sectioned from each branchlet. Cross-sections of the needles were made with a razor blade at their mid-points. The sections were placed on glass slides in a solution 1:3 of glycerine in alcohol to prevent dessication during their examination under a light-microscope.
Besides the provenances and species growing in the experimental plantation, $A$ pinsapo was sampled by visiting its natural population in southern Spain (Sierra de la Nieves). Samples were randomly collected from 15 seedlings which were not more than 6-10 years old and 15 mature trees. From each seedling one branchlet was obtained from the previous year's whorl, while from the mature trees one branchlet from the lower, the middle and the upper part of their crown, respectively was taken whenever it was possible. The samples were put in plastic bags and transferred to our laboratory, and stored in the refrigerator together with the rest of the samples prior to examination.

Data obtained was statistically analysed by binomal distribution and the correlation coefficient between latitude and percent of marginal resin canals of Greek provenances was computed (Steel and Torrie, 1980; Fotiadis, 1985).

\section{RESULTS}

The results obtained can be summarized as follows: in the lower branches, regardless of provenance or species and crown orientation all needles developed marginal resin canals. After a certain height and age, however, 2 kinds of tree can be found: 1), trees with marginal resin canals up to their top, ie Type 1 (fig 3); and 2), trees in which the position of the resin canals gradually starts to change and eventually becomes median, ie Type 2 (fig 4).

In table $\mathrm{I}$ and figure 1 , the results are presented on the total number of species and provenances which were included in this investigation. It is evident that in Greek fir the proportion of trees with marginal resin canals decreases from provenance 1 (south) to provenance 16 (north) (correlation coefficient $r=-0.7949$ ); this can further be separated into groups by applying the $z$-criterion to compare pairs of provenances with respect to percentage of marginal resin canals (see fig 2). 


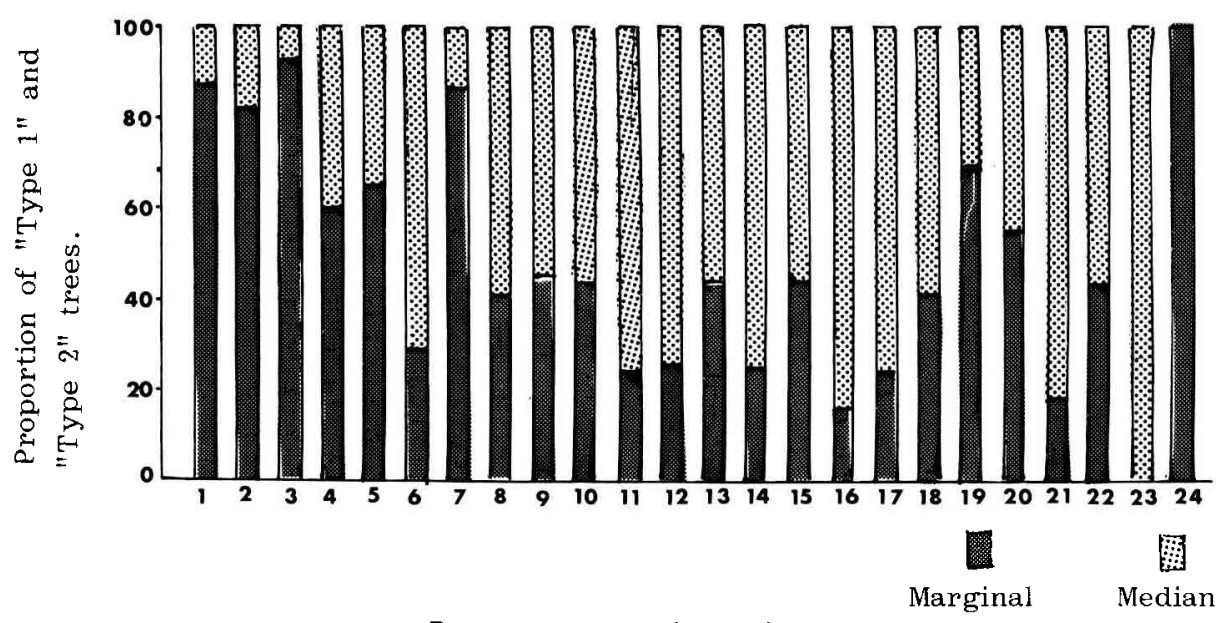

Provenances and species

Fig 1. Proportion of trees with marginal resin canals throughout their crown (Type 1) and Type 2 trees with median resin canals after a certain age, in various provenances and species (see table I for identification of the code numbers 1-24).

It should be mentioned that according to Mattfeld (1930) the southern populations up to latitude $38^{\circ} 50^{\prime}$, are considered as belonging to the species Abies cephalonica while the rest are natural hybrids between $A$ cephalonica $\times A$ alba which at the time Mattfeld collectively designated as $A \times$ borsii regis (no longer valid).

\section{DISCUSSION}

The results obtained clearly show that in all provenances, species and hybrids studied, adult trees at a young stage and up to an unspecified height developed needles with marginal resin canals. These findings were expected, since in the nursery stage the same material (Panetsos, 1975) developed marginal resin canals regardless of provenance, species of hybrids. It seems that the marginal location of resin canals at a juvenile stage is a common featu'e in the genus Abies. Kormutäk (1985), comparing the position of the resin canals of 9 Abies species and their hybrids from seedling samples, stated: "The rigidly fixed marginal position of the resin canals revealed in all the parental species, was also constant feature of the hybrids examined". Roller (1966) also reported that the position of the resin canals is marginal in seedlings of $A$ balsamea, $A$ lasiocarpa, and $A$ fraseri in the USA, whereas in the needles of the adult and mature trees of the same species, the position changed to median.

Furthermore, it was found that the position of the resin canals in the needles of the adult trees varies from species to species and even among and within populations of the same species. Based on our results, 3 categories of species and hybrids can be distinguished: a) species in which the adult trees develop needles with marginal resin canals throughout their crown (ie A concolor; b) species or hybrids 


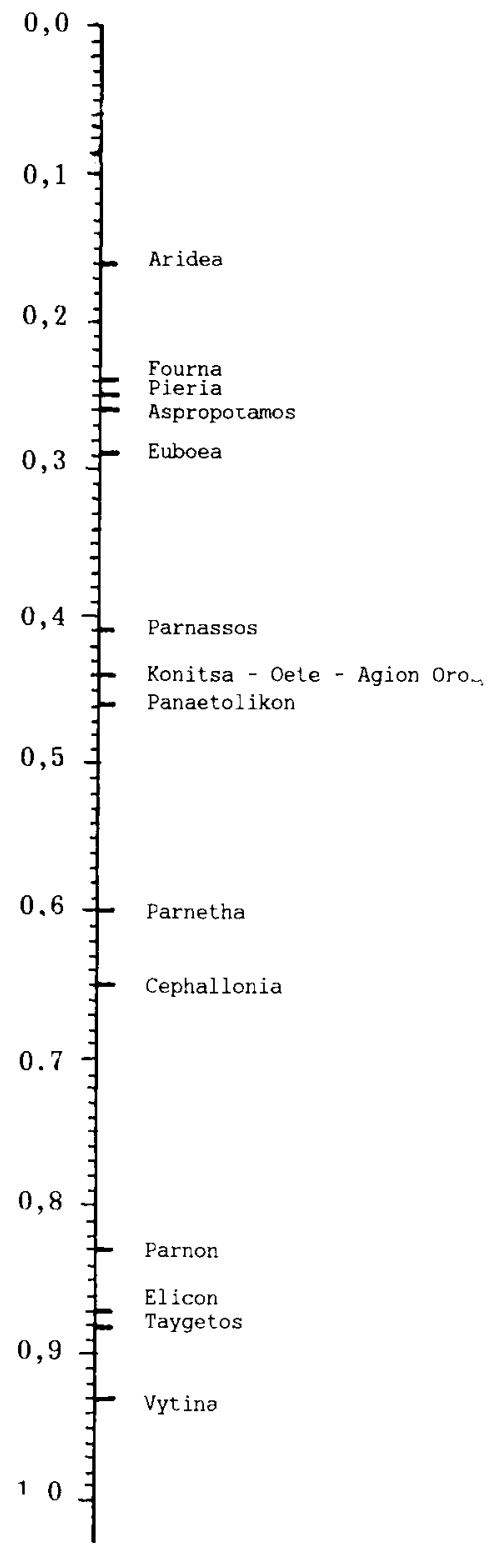

a

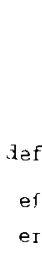

Fig 2. Frequency of marginal resin canals in provenances of Greek fir. Provenances with the same letter $(a, b, c, d, e, f)$ do not differ significantly from one another $(P=0.05)$. with Type 1 or Type 2 trees in various proportions in their populations (see table I and fig 1); c) species in which the adult trees at the young stage (lower part of the crown) develop marginal resin canals while at a certain age and height (not fixed) the location of the resin canals changes to median in the rest of their crown (ie, $A$ pinsapo). It appears that the American firs $A$ balsamea, $A$ lasiocarpa and $A$ fraseri (Roller, 1966) belong to the latter category. The above-mentioned author concluded that the change in the position of the resin canals appears to be under genetic control in the 3 species which he examined, and not as much affected by ecological factors, as was supposed earlier. Environmental factors may modify the rate at which a tree matures and so affect the time at which the change in resin canals position occurs.

Considering the results obtained from the common environment plantation, in the Greek fir both types of trees occur in all populations examined. The frequency, however, of Type 1 trees with marginal resin canals decreases from south to

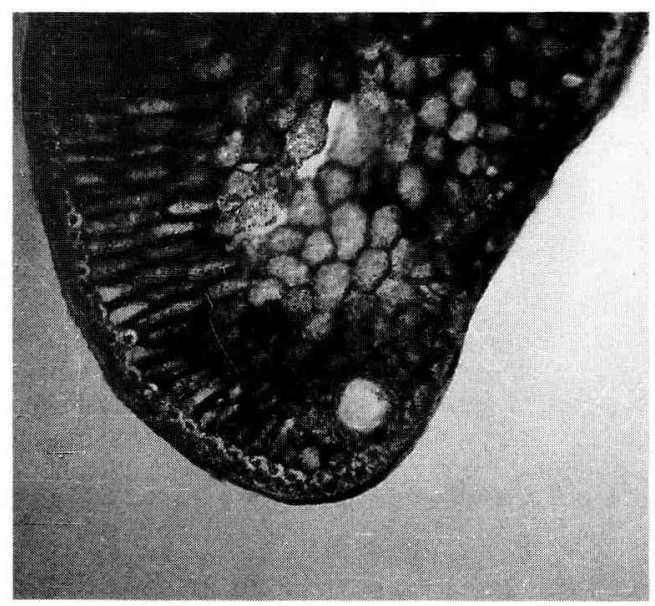

Fig 3. Marginal resin canal ( $x 75$ ). 


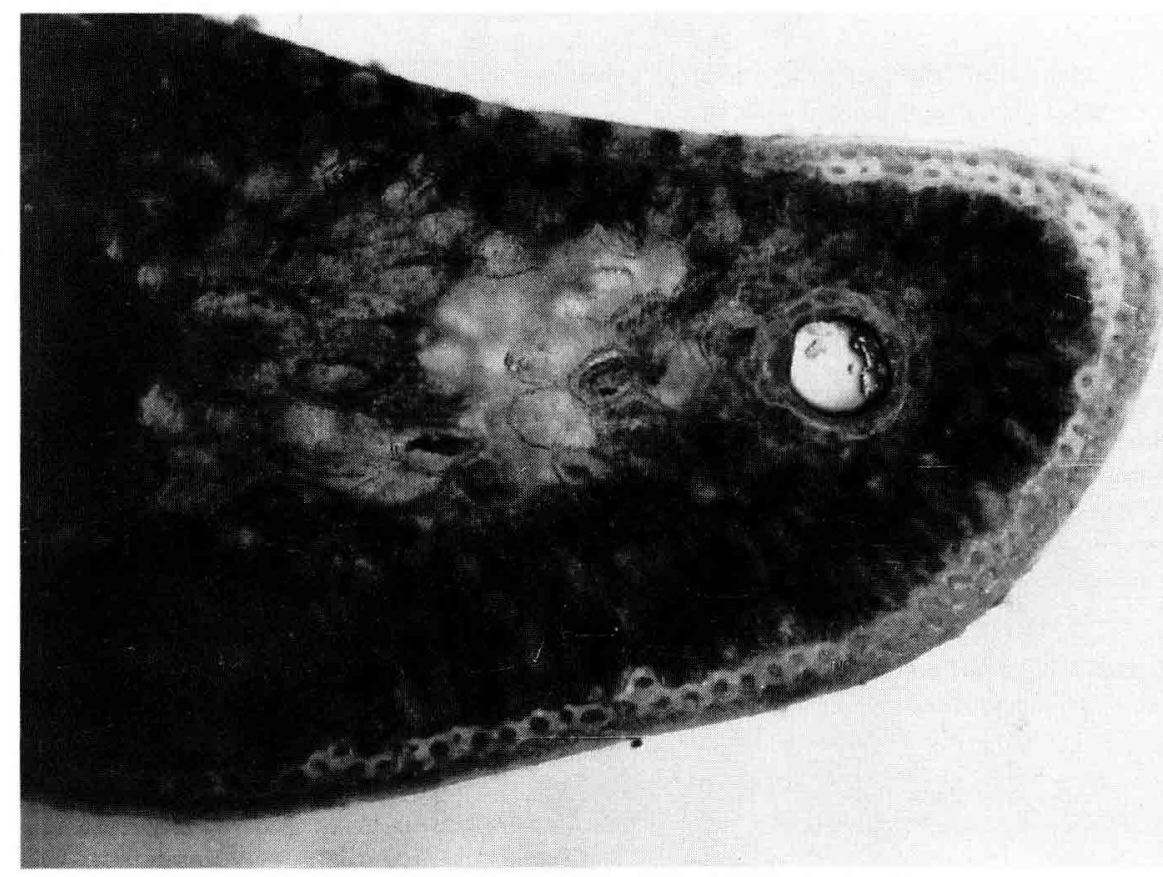

Fig 4. Median resin canal (x 100).

north. Indeed, the estimated correlation coefficient between provenances and latitude with respect to the frequency of type 1 trees is high $(r=-0,7949)$. The populations can be separated into groups (fig 2) which more or less coincide with the clusters of provenances determined by the average between cluster $\mathrm{D}^{2}$ values for monoterpenes (Mitsopoulos and Panetsos, 1987). The southern group $(1,2,3$ and 7$)$ in this study represents the core of $A$ cephalonica distribution in Greece, while the rest of the populations are strongly introgressed by $A$ alba characters or are hybrid swarms. Fady et al (1990) in an investigation based on terpene composition also differentiated the Peloponnese populations from the rest of the Greek fir population except for the populations of Parnetha and Parnassos which form a cluster with the Peloponnese populations. Elicon (pop No 7) was not included in their sample.

Abies alba, which in this investigation is represented by 4 populations of Italian origin, can be classified as a category (b) species with respect to the position of resin canals in the needles. The 4 populations are highly variable, with a clear tendency in the frequency of marginal resin canals to decline from south to north with the exception of provenance No 65. This particular population according to Ducci (personal communication) is an artificial one which comes from seeds of German origin. 
On the same subject, Klaehn and Winieski (1962) and Liu (1971) consider $A$ x borisii regis as having needles with median resin canals and the parental species ( $A$ alba and $A$ cephalonica) as marginal. This generalization is not valid, as was shown from the results obtained in this investigation. The discrepancies probably arise from improper sampling of the species concerned.

When examining evolution in the genus Abies, Gaussen (1937) classified firs with median resin canals as primitive and those with marginal as evolved. According to this theory, $A \times$ borisii regis should be more primitive than at least one of its supposed parents ( $A$ cephalonica). The question then arises as to whether the intergradation found in the area of $A$ borisii regis natural distribution is primary or secondary. Extensive investigation by Mitsopoulos and Panetsos (1987) conclusively showed that the intergradation is secondary, ie it originated to a large extent from natural hybridization of the pre-existing species $A$ alba and $A$ cephalonica. After this short discussion it can be stated that Gaussen's theory is not applicable (at least for populations of hybrid origin) and that firs of Type 1 trees with marginal resin canals throughout their crown might be considered as primitive.

\section{ACKNOWLEDGMENTS}

I am grateful to numerous collegues at the Forest Research Station of Central Greece for their assistance to the collection of samples. In particular, thanks are due to P Alizoti for statistical help and $C$ Cypriotou for careful laboratory work. This study was financed by the EEC projet, "Adaptation, Breeding and Sylviculture of Mediterranean Firs", Contract No MAIB/0097, GR (TT).

\section{REFERENCES}

Bassiotis K (1956) Fir Forest of Greece. Year Book Agric For Univ Thessaloniki, 1-89

Catalan G, Pardos JA (1983) Genetics of Abies pinsapo. Ann For (Zagreb) 185-208

Fady B, Arbez M, Marreau A (1990) Hypothèses sur l'évolution du genre Abies autour de la mer Egée depuis la fin du Tertiaire : contribution de l'analyse de la variabilité terpenique. Int Workshop on Mediterranean Firs. EEC Catalogue No CD-NA-13491-2A-C

Ferré $Y$ de (1941) La place des canaux résinifères dans les feuilles des Abiétenées. Bull Soc Hist Nat Toulouse T. 76, 3

Fotiadis N (1985) Introduction to Statistics for Biological Sciences. Univ Studio Press, Thesaloniki, Greece

Gaussen $H$ (1937) Les formes de jeunesse et l'évolution future. CR Acad Sci (Paris) 204 (10), 800-802

Klaehn FV, Winieski JA (1962) Interspecific hybridization in the genus Abies. Silvae Genet $11,130-142$

Kormutäk A (1985) Study on species hybridization within the genus Abies. Acta Dendrol (Bratislava)

Liu TS (1971) A monograph of the genus Abies. For Coll Agr Nat Taiwan Univ, $608 \mathrm{p}$

Mattfeld J (1930) Uber hybridogene Sippen der Tanne. Bib/ Bot 100, 1-84

Mitsopoulos DJ, Panetsos KP (1987) Origin of variation in fir forest of Greece. Silvae Genet $36,1-15$

Moulalis D (1986) Diagnosis and description of Abies hybrids. Ann Dept For, Natl Environ, Univ Thessaloniki, vol 19, 371-404 (in Greek, German summary)

Panetsos KP (1975) Monograph of Abies cephaIonica Loudon. Yugosl Acad Sci Ann For 7 , $1-22$

Roller JD (1966) Resin canal position in the needles of balsam, alpine and Fraser firs. For Sci 5 (12), 348-355

Steel R, Torrie J (1980) Principles and Procedures of Statistics. A Biometrical Approach. Mc Graw Hill Book Co, New York 